\title{
Changes in soil phosphorus fractions after 9 years of continuous nitrogen addition in a Larix gmelinii plantation
}

\author{
Kai Yang • Jiaojun Zhu • Jiacun Gu • \\ Lizhong Yu $\cdot$ Zhengquan Wang
}

Received: 29 August 2014 / Accepted: 28 November 2014 / Published online: 19 December 2014

(C) INRA and Springer-Verlag France 2014

\begin{abstract}
- The key message $\mathbf{N}$ addition decreased soil inorganic $\mathrm{P}$ availability, microbial biomass $P$, and acid phosphatase activity in the larch plantation. Soil inorganic $P$ availability decreased after $\mathbf{N}$ addition due to the changes in both microbial properties and plant uptake.

- Context Soil phosphorus (P) availability is considered an important factor in influencing the biomass production of plants. Sustained inputs of nitrogen $(\mathrm{N})$ through atmospheric
\end{abstract}

Handling Editor: Andreas BOLTE

Contribution of the co-authors Kai Yang-designed and ran the experiment, analyzed the data, and wrote the manuscript.

Jiaojun Zhu — supervised the experiment design and data analysis and wrote the manuscript.

Jiacun $\mathrm{Gu}$ - sample analysis and gave the help in running the experiment. Lizhong $\mathrm{Yu}$ - sample analysis and gave the help in running the experiment.

Zhengquan Wang - designed the experiment and gave the suggestions to the composition of manuscript.

Electronic supplementary material The online version of this article (doi:10.1007/s13595-014-0444-7) contains supplementary material, which is available to authorized users.

K. Yang $\cdot$ J. Zhu $\cdot$ L. Yu

Qingyuan Forest CERN, Chinese Academy of Sciences,

Shenyang 110016, People's Republic of China

K. Yang $\cdot$ J. Zhu

State Key Laboratory of Forest and Soil Ecology, Institute of Applied Ecology, Chinese Academy of Sciences, Shenyang 110164, People's Republic of China

J. Gu $\cdot$ Z. Wang

School of Forestry, Northeast Forestry University, Harbin 150040,

People's Republic of China

\section{J. Zhu $(\bowtie)$}

Institute of Applied Ecology, Chinese Academy of Sciences, 72

Wenhua Road, Shenyang 110016, People's Republic of China

e-mail: jiaojunzhu@iae.ac.cn deposition or $\mathrm{N}$ fertilizers, particularly in temperate forests, may change the composition and availability of $\mathrm{P}$ and thus affect long-term forest productivity.

- Aims The objective of this study was to assess soil P availability, $\mathrm{P}$ fractions, and microbial properties including microbial biomass $\mathrm{P}$ and acid phosphatase activity after 9 consecutive years of $\mathrm{N}$ addition in a larch (Larix gmelinii) plantation, northeastern China.

- Methods From 2003 to 2011, $\mathrm{NH}_{4} \mathrm{NO}_{3}$ was added to replicate plots (three $20 \mathrm{~m} \times 30 \mathrm{~m}$ plots) in the larch plantation each year at a rate of $100 \mathrm{~kg} \mathrm{~N} \mathrm{ha}^{-1}$ year $^{-1}$. Soil samples from $0-10$ $\mathrm{cm}$ and 10-20-cm depths were collected in $\mathrm{N}$ addition plots and control (no $\mathrm{N}$ addition) plots.

- Results $\mathrm{N}$ addition significantly decreased soil $\mathrm{NaHCO}_{3}-\mathrm{Pi}$ ( $\mathrm{Pi}$ is inorganic $\mathrm{P}$ ), microbial biomass $\mathrm{P}$, and acid phosphatase activity but increased the $\mathrm{NaOH}-\mathrm{Pi}$ concentration. $\mathrm{N}$ addition appeared to induce a decrease in soil inorganic $\mathrm{P}$ availability by changing $\mathrm{pH}$ and $\mathrm{P}$ uptake by trees. In addition, $\mathrm{N}$ addition significantly decreased the NaOH-Po (Po is organic P) concentration, possibly because of increased $\mathrm{P}$ mineralization. However, the total $\mathrm{P}$ and other $\mathrm{P}$ fractions were unaffected by $\mathrm{N}$ fertilization.

- Conclusion Our results suggested that $\mathrm{N}$ addition enhanced $\mathrm{P}$ uptake by trees, whereas it reduced soil inorganic $\mathrm{P}$ availability as well as microbial biomass and activity related to soil $\mathrm{P}$ cycling in the larch plantation.

Keywords Larch plantation · Microbial biomass P . Phosphorus availability $\cdot$ Phosphatase activity

\section{Introduction}

Nitrogen $(\mathrm{N})$ is generally believed to be the one nutrient limiting primary productivity in a wide variety of terrestrial ecosystems (LeBauer and Treseder 2008), particularly in 
temperate forest ecosystems with relatively young soils (Vitousek and Howarth 1991). Thus, fertilization with $\mathrm{N}$ often stimulates tree growth, resulting in increased plant production in such ecosystems (Thomas et al. 2010). Recently, increased plant production after $\mathrm{N}$ enrichment has led to a concern that forest ecosystems may be limited by other important nutrients such as phosphorus (P) (Braun et al. 2010). Although studies have focused on the impact of increased $\mathrm{N}$ on carbon (C) cycling (Sinsabaugh et al. 2005; Nave et al. 2009; Cusack et al. 2010), the question of how increased $\mathrm{N}$ affects the availability and cycling of $\mathrm{P}$ in forest soils receives little attention. Given that $\mathrm{P}$ is an important structural component of nucleotides, phospholipids, and nucleic acids in plants (Schachtman et al. 1998), it is important to understand the effect of $\mathrm{N}$ addition on the forms and availability of $\mathrm{P}$ in soils.

The $\mathrm{P}$ in terrestrial ecosystems exists in many complex chemical forms, including inorganic mineral forms and organic forms, which differ markedly in their behavior, mobility, and bioavailability in the soils. Studies have reported that soil $\mathrm{P}$ availability, especially inorganic $\mathrm{P}$, is directly linked to net primary productivity (Herbert and Fownes 1995; Paoli and Curran 2007; Baribault et al. 2012). In forest soils, $N$ addition may stimulate primary production and increase biotic $\mathrm{P}$ demand, therefore decreasing soil inorganic $\mathrm{P}$ availability (Vitousek et al. 2010). Mycorrhizae may play an important role in the plants because they may affect uptake of relatively immobile nutrients, such as $\mathrm{P}$, then changing soil $\mathrm{P}$ availability (Clark and Zeto 2000). It has been suggested that $\mathrm{N}$ inputs may significantly enhance nutrient cycling in the terrestrial ecosystems via stimulation of root growth and mycorrhizal functioning (Tu et al. 2006). In addition, $\mathrm{N}$ addition decreases soil $\mathrm{pH}$, which then mobilizes soil aluminum and iron, therefore reducing available $\mathrm{P}$ through increased $\mathrm{P}$ sorption and decreased mineralization of organic matter (Carreira et al. 2000). The content and forms of soil organic $P$ may also be influenced by $\mathrm{N}$ addition through changes in organic matter input (Khan et al. 2008). Taken together, if continued $\mathrm{N}$ addition changes the soil $\mathrm{P}$ cycle, then understanding how the soil $\mathrm{P}$ status changes in response to $\mathrm{N}$ addition will be important for predicting forest ecosystem function.

Nitrogen addition could influence soil P availability through microbial changes, especially phosphatase enzyme activity (Marklein and Houlton 2012). For example, phosphatase enzyme is rich in $\mathrm{N}$, meaning that soil microorganisms must sacrifice $\mathrm{N}$ to get $\mathrm{P}$ via this path (Olander and Vitousek 2000). In addition, from a functional perspective, the phosphatase enzyme response to $\mathrm{N}$ addition has received considerable attention because this enzyme contributes to the processes controlling organic $\mathrm{P}$ mineralization (Criquet et al. 2004). Studies that examined phosphatase enzyme activities after $\mathrm{N}$ addition in different forests have produced contradictory results. One study reported that soils underlying a Eucalyptus dunnii plantation after $\mathrm{N}$ addition increased in both phosphatase activity and P availability (Wang et al. 2008), while another study showed no significant change in phosphatase activity after $\mathrm{N}$ addition in young spruce stands in Sweden (Clarholm 1993). Importantly, the response of phosphatase enzyme activity to added $\mathrm{N}$ has direct effect (increase in $\mathrm{N}$ availability) or indirect effects (changes in $\mathrm{pH}$ or concentrations of cations/anions other than $\mathrm{N}$ availability). To better illustrate soil $\mathrm{P}$ status after $\mathrm{N}$ addition in temperate forests, we need to understand how soil phosphatase enzyme activity was affected by added $\mathrm{N}$.

During the last few decades, rapid economic development in China has resulted in accelerated $\mathrm{N}$ deposition (Lü and Tian 2007). Northern China is considered one of the main $\mathrm{N}$ deposition areas in Asia. The $\mathrm{N}$ deposition levels in northern China are in the range of 28.5-100.4 kg N ha ${ }^{-1}$ year $^{-1}$ (Pan et al. 2012). Larch species are widely distributed throughout northern Asia, and many are important forestry species (Wang et al. 2006; Ohsawa and Shimokawa 2011). In previous studies, the effects of $\mathrm{N}$ addition on soil respiration, microbial properties, and methane and nitrous oxide fluxes have been investigated (Hu et al. 2010; Jia et al. 2010; Kim et al. 2012). However, little is known about how $\mathrm{N}$ addition may alter soil $\mathrm{P}$ status in larch plantations.

In this study, we investigated soil $\mathrm{P}$ forms and the microbial properties affecting $\mathrm{P}$ cycling and transformation (i.e., microbial biomass $\mathrm{P}$ and acid phosphatase activity) in response to 9 consecutive years of $\mathrm{N}$ addition in a larch (Larix gmelinii) plantation in northeastern China. At this site, previous study has shown that $\mathrm{N}$ addition significantly decreased soil $\mathrm{pH}$ and microbial biomass (Hu et al. 2010) but increased P concentration in plant tissues (Zhao et al. 2010). We hypothesized that soil $\mathrm{P}$ availability and $\mathrm{P}$ fractions would change after $\mathrm{N}$ addition due to the changes in both biochemical ( $\mathrm{pH}$ and microbial biomass and activity) properties and plant uptake.

\section{Material and methods}

\subsection{Study site and experimental design}

This study was conducted at the Maoershan Experimental Station of Northeast Forestry University, located in a mountainous area, Heilongiiang Province, China $\left(45^{\circ} 21^{\prime}-45^{\circ} 25^{\prime}\right.$ $\left.\mathrm{N}, 127^{\circ} 30^{\prime}-127^{\circ} 34^{\prime} \mathrm{E}\right)$. The region has a continental monsoon climate with mean annual temperature of $2.8^{\circ} \mathrm{C}$, mean minimum temperature of $-19.6{ }^{\circ} \mathrm{C}$ in January, and mean maximum temperature of $20.1^{\circ} \mathrm{C}$ in July. The growing season is from early May to late September. Mean annual precipitation is approximately $700 \mathrm{~mm}$, with $>60 \%$ falling between June and August. The frost-free period is between 120 and 140 days (Zhou 1994). The soil is Hap-Boric Luvisol (Gong et al. 1999). Soil depth of the study site exceeds $50 \mathrm{~cm}$ and with high organic matter content. The soil is a loam soil in the 
$0-10-\mathrm{cm}$ depth and a sandy loam soil in the 10-20-cm depth. More details about the soil were given by Wang et al. (2006).

Larch is the key commercial tree species and represents $65 \%$ of conifer plantations in northeast China (Wang et al. 2006). In this study, a larch (L. gmelinii) plantation was selected on a southwest facing slope of approximately $13^{\circ}$, with an elevation ranging from 450 to $500 \mathrm{~m}$ above sea level. The plantation was established in 1986 by planting 2 -year-old seedlings using a $1.5 \mathrm{~m} \times 2.0 \mathrm{~m}$ planting grid. At the beginning of the experiment, the tree density, mean tree diameter at breast height, and tree height were 2267 trees ha $^{-1}, 10.9 \mathrm{~cm}$, and $11.3 \mathrm{~m}$ in the larch plantation; see Mei et al. (2010) for more details on stand characteristics.

Nitrogen addition plots were established in the plantation in May 2002. Three $20 \mathrm{~m} \times 30 \mathrm{~m}$ ammonium nitrate $\left(10 \mathrm{~g} \mathrm{~N} \mathrm{~m}^{-1}\right.$ year $\left.^{-1}\right)$ fertilized plots were paired with control plots of the same size, with each plot surrounded by $\geq 10$-mwide buffer strip. Therefore, a total of six plots were established for soil sample collection. $\mathrm{N}$ addition experiments were initiated in 2003. Ammonium nitrate was applied in pellet form each year between 2003 and 2011. All of the $10 \mathrm{~g} \mathrm{~N} \mathrm{~m}^{-1}$ year $^{-1}$ was applied each year during the growing season, with $15.25 \%$ of the fertilizer added in May and in September, $21 \%$ in June and in August, and $27.5 \%$ in July. The amount of fertilizer applied each month was designed to track the natural temporal patterns of $\mathrm{N}$ mineralization that occurs at the site in each particular month (Chen et al. 1999).

\subsection{Soil sampling}

Soils were sampled from each plot in August (approximately 3 weeks after the last addition of $\mathrm{N}$ in July) 2011. Fifteen soil cores ( $5 \mathrm{~cm}$ in diameter) were taken randomly from each plot after removal of the forest floor litter and sectioned into 0-10$\mathrm{cm}$ and 10-20-cm depths. The cores were then mixed to form a composite soil sample for each soil depth. Soil was sieved $(<4 \mathrm{~mm})$ and stored at $4{ }^{\circ} \mathrm{C}$ for later analysis after visible roots and plant residues were removed. Soil samples were further divided into three sets of sub-samples. One set of the subsamples was processed to pass through a $2-\mathrm{mm}$ sieve and stored at $4{ }^{\circ} \mathrm{C}$ for measurement of microbial biomass $\mathrm{P}$ and acid phosphatase activity, one set was air-dried and passed through a $0.5-\mathrm{mm}$ sieve for analysis of soil $\mathrm{pH}$ and $\mathrm{P}$ fractionation, and the remaining set of sub-samples was oven-dried and homogenized and passed through a $0.25-\mathrm{mm}$ sieve for analyses of soil organic carbon $(\mathrm{C})$ and total nitrogen $(\mathrm{N})$. The selected soil chemical properties are listed in Table 1.

\subsection{Soil analyses}

Soil organic $\mathrm{C}$ and $\mathrm{N}$ were analyzed by dry combustion using a Vario EL III elemental analyzer (Elementar Analysensysteme $\mathrm{GmbH}$, Hanau, Germany). Ammonium $\left(\mathrm{NH}_{4}{ }^{+} \mathrm{N}\right)$ and nitrate
$\left(\mathrm{NO}_{3}{ }^{-} \mathrm{N}\right)$ were extracted with $2 \mathrm{M} \mathrm{KCl}$ and analyzed on an auto analyzer (Auto Analyzer III, Bran+Luebbe GmbH, Germany). Extractable $\mathrm{Al}$ and $\mathrm{Fe}$ were extracted with acid ammonium oxalate, and extracts were analyzed by inductively coupled plasma mass spectrometry (Agilent Technologies Co. Ltd, USA). Soil $\mathrm{pH}$ was estimated from a 1:2.5 soil-water slurry.

Soil $\mathrm{P}$ was sequentially fractionated following a modified version of the Hedley et al. (1982) fractionation scheme. Briefly, $0.5 \mathrm{~g}$ of soil was successively extracted with $30 \mathrm{~mL}$ deionized water, $0.5 \mathrm{~mol} \mathrm{~L}^{-1} \mathrm{NaHCO}_{3}(\mathrm{pH} 8.5), 0.1 \mathrm{~mol} \mathrm{~L}^{-1}$ $\mathrm{NaOH}$, and $1 \mathrm{~mol} \mathrm{~L}^{-1} \mathrm{HCl}$ for $17 \mathrm{~h}$ each. The inorganic $\mathrm{P}(\mathrm{Pi})$ concentration of each extract was determined and referred to as either water-soluble $\left(\mathrm{H}_{2} \mathrm{O}\right.$-soluble $)$ or $\mathrm{NaHCO}_{3}-, \mathrm{NaOH}$, or $\mathrm{HCl}$-extractable $\mathrm{Pi}$ fractions. The residue was digested using $\mathrm{H}_{2} \mathrm{SO}_{4}+\mathrm{H}_{2} \mathrm{O}_{2}$ at $360{ }^{\circ} \mathrm{C}$ for the measurement of residual $\mathrm{P}$ (Tiessen and Moir 1993). The total $\mathrm{P}$ concentration of each extract was also determined after acid persulfate digestion (autoclaving for $30 \mathrm{~min}$ at $121{ }^{\circ} \mathrm{C}$ and $1.05 \mathrm{~kg} \mathrm{~cm}^{-1}$ pressure). The organic $\mathrm{P}(\mathrm{Po})$ concentration of these extracts was calculated as the difference between total and inorganic $\mathrm{P}$, referred to as the $\mathrm{H}_{2} \mathrm{O}-, \mathrm{NaHCO}_{3}-, \mathrm{NaOH}-$, or $\mathrm{HCl}$-extractable Po fractions. The soil total $\mathrm{P}$ was the sum of all $\mathrm{P}$ fractions.

Soil microbial biomass $\mathrm{P}$ was determined using the chloroform fumigation extraction method. The microbial biomass $\mathrm{P}$ was estimated from the relationship $E_{\mathrm{P}} / K_{\mathrm{EP}}$, where $E_{P}$ is the difference between inorganic $\mathrm{P}$ extracted from fumigated and unfumigated soils and $K_{\mathrm{EP}}=0.40$ (Brookes et al. 1982). The correction for chloroform-released $\mathrm{P}$ that was absorbed by soil colloids during extraction was made by adding $25 \mathrm{mg} \mathrm{P} \mathrm{kg}^{-1}$ soil during extraction and then correcting for its recovery (Brookes et al. 1982).

Acid phosphatase activity was determined according to the method of Tabatabai (1994). Briefly, soil samples were incubated with $p$-nitrophenyl phosphate ( $p$-NPP) as the substrate for $1 \mathrm{~h}$, the reaction was terminated with $0.5 \mathrm{M} \mathrm{NaOH}$ and $0.5 \mathrm{M} \mathrm{CaCl}_{2}$, and the absorbance was determined spectrophotometrically at $400 \mathrm{~nm}$. Controls without enzymes were processed in parallel to determine non-enzymic hydrolysis of the substrate and to correct for background coloration. Enzyme activities are expressed as $\operatorname{mg} p$ - NPP kg ${ }^{-1}$ soil $\mathrm{h}^{-1}$. Controls without soil were processed in parallel to correct for background coloration.

\subsection{Statistical analyses}

Analysis of variance (ANOVA) of a split-plot design with the treatments as the whole plot and the sampling depths as the split plot was performed to determine whether $\mathrm{N}$ addition significantly affected soil $\mathrm{P}$ fractions, microbial biomass $\mathrm{P}$, and acid phosphatase activity. These statistical analyses were conducted using SAS version 9.2 (SAS Institute Inc., Cary, NC, USA). 
Table 1 Changes in selected soil chemical properties after 9 years of $\mathrm{N}$ addition in the larch plantation

\begin{tabular}{|c|c|c|c|c|c|c|c|c|}
\hline Soil depth/treatments & $\begin{array}{l}\text { Organic C } \\
\left(\mathrm{g} \mathrm{kg}^{-1}\right)\end{array}$ & $\begin{array}{l}\text { Total N } \\
\left(\mathrm{g} \mathrm{kg}^{-1}\right)\end{array}$ & Soil C:N & $\begin{array}{l}\mathrm{NH}_{4}^{+}-\mathrm{N} \\
\left(\mathrm{mg} \mathrm{kg}^{-1}\right)\end{array}$ & $\begin{array}{l}\mathrm{NO}_{3}^{-}-\mathrm{N} \\
\left(\mathrm{mg} \mathrm{kg}^{-1}\right)\end{array}$ & $\begin{array}{l}\text { Extractable Al } \\
(\%)\end{array}$ & $\begin{array}{l}\text { Extractable Fe } \\
(\%)\end{array}$ & $\mathrm{pH}$ \\
\hline \multicolumn{9}{|l|}{$0-10-\mathrm{cm}$ depth } \\
\hline Control & $80.8 \mathrm{a}$ & $7.2 \mathrm{a}$ & $11.2 \mathrm{~b}$ & $3.5 \mathrm{a}$ & $23.9 \mathrm{~b}$ & $0.231 \mathrm{~b}$ & $0.309 \mathrm{~b}$ & $5.8 \mathrm{a}$ \\
\hline $\mathrm{N}$ addition & $85.4 \mathrm{a}$ & $7.3 \mathrm{a}$ & $11.7 \mathrm{a}$ & $3.0 \mathrm{a}$ & $91.7 \mathrm{a}$ & $0.254 \mathrm{a}$ & $0.316 \mathrm{~b}$ & $5.3 \mathrm{~b}$ \\
\hline \multicolumn{9}{|l|}{ 10-20-cm depth } \\
\hline Control & $48.1 \mathrm{~b}$ & $5.0 \mathrm{~b}$ & $9.6 \mathrm{c}$ & $2.6 \mathrm{a}$ & $12.3 \mathrm{c}$ & $0.255 \mathrm{a}$ & $0.358 \mathrm{a}$ & $6.0 \mathrm{a}$ \\
\hline $\mathrm{N}$ addition & $46.6 \mathrm{~b}$ & $4.6 \mathrm{~b}$ & $10.0 \mathrm{c}$ & $2.4 \mathrm{a}$ & $48.6 \mathrm{~b}$ & $0.278 \mathrm{a}$ & $0.353 \mathrm{a}$ & $5.8 \mathrm{a}$ \\
\hline
\end{tabular}

Values are means for $n=3$. Different letters within a column indicate significant differences at $P<0.05$

\section{Results}

\subsection{Soil properties}

Of the selected soil chemical properties, soil organic $\mathrm{C}$ and $\mathrm{N}$, $\mathrm{NH}_{4}{ }^{+}-\mathrm{N}$, and extractable $\mathrm{Fe}$ were not affected by $\mathrm{N}$ addition (Table 1). By comparison, the soil-extractable $\mathrm{Al}$ and C-to- $\mathrm{N}$ ratio increased significantly after $\mathrm{N}$ addition at a depth of 0 $10 \mathrm{~cm}$. Soil $\mathrm{NO}_{3}{ }^{-}-\mathrm{N}$ increased significantly after $\mathrm{N}$ addition in both $0-10-\mathrm{cm}$ and $10-20-\mathrm{cm}$ depths. The soil $\mathrm{pH}$ value at the $0-10-\mathrm{cm}$ depth in the $\mathrm{N}$ addition plots was 0.5 units lower than those in the control plots. Soil chemical properties changed with soil depth (Table 1). Soil organic $\mathrm{C}$ and $\mathrm{N}$ and the soil C-to-N ratio at the $0-10-\mathrm{cm}$ depth were greater than those at the 10-20-cm depth for both the control and the $\mathrm{N}$ addition plots. However, differences in soil $\mathrm{pH}$ between the 0 $10-\mathrm{cm}$ and $10-20-\mathrm{cm}$ depths were only observed in the $\mathrm{N}$ addition plots.

\subsection{Soil total $\mathrm{P}$ and $\mathrm{P}$ fractions}

Soil total P concentrations, i.e., the sum of the concentrations of all $P$ fractions, at both sampling depths were not affected by $\mathrm{N}$ addition (Fig. 1). Soil total $\mathrm{P}$ at the $0-10-\mathrm{cm}$ depth was greater than that at the 10-20-cm depth for both the control and $\mathrm{N}$ addition plots. The relative size of the $\mathrm{P}$ pools increased

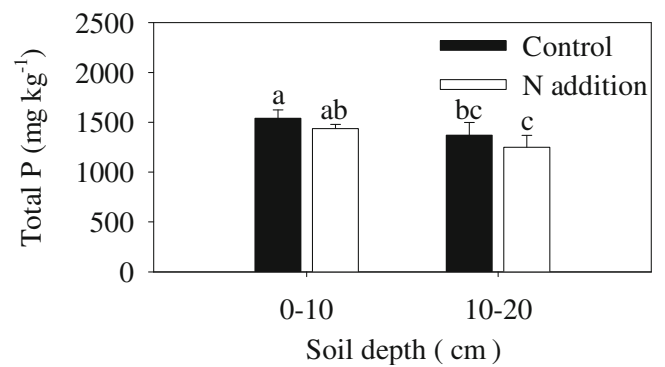

Fig. 1 Changes in soil total $\mathrm{P}$ concentration (the sum of the concentrations of all fractions) after 9 years of $\mathrm{N}$ addition in the larch plantation. Bars represent means with standard errors for $n=3$. Different letters indicate significant differences at $P<0.05$ in the order $\mathrm{H}_{2} \mathrm{O}-\mathrm{Pi} \approx \mathrm{H}_{2} \mathrm{O}-\mathrm{Po}<\mathrm{HCl}-\mathrm{Po}<\mathrm{NaHCO}_{3}-\mathrm{Pi}<$ $\mathrm{NaHCO}_{3}-\mathrm{Po}<\mathrm{HCl}-\mathrm{Pi}<\mathrm{NaOH}-\mathrm{Pi}<\mathrm{NaOH}-\mathrm{Po}<$ Residual-P (Figs. 2 and 3) for both the control and $\mathrm{N}$ addition plots.

$\mathrm{N}$ addition significantly reduced the $\mathrm{NaHCO}_{3}-\mathrm{Pi}$ concentration that is commonly considered as labile $\mathrm{P}$ pool (Fig. 2). In contrast, the $\mathrm{NaOH}-\mathrm{Pi}$ concentration at the $0-10-\mathrm{cm}$ depth in the $\mathrm{N}$ addition plots was significantly higher than that in the control plots. There were no significant changes in the $\mathrm{H}_{2} \mathrm{O}-\mathrm{Pi}$ and $\mathrm{HCl}-\mathrm{Pi}$ concentrations in the $\mathrm{N}$ addition plots. The $\mathrm{Pi}$ fractions extracted by $\mathrm{H}_{2} \mathrm{O}, \mathrm{NaHCO}_{3}$, and $\mathrm{NaOH}$ at the 0 $10-\mathrm{cm}$ depth were markedly higher than those at the 10-20$\mathrm{cm}$ depth for both treatments but not for the $\mathrm{HCl}-\mathrm{Pi}$ fraction.

The NaOH-Po concentration at the $0-10-\mathrm{cm}$ depth in the $\mathrm{N}$ addition plots was significantly lower than that in the control plots. However, the Po fractions extracted by $\mathrm{H}_{2} \mathrm{O}, \mathrm{NaHCO}_{3}$, and $\mathrm{HCl}$ were similar between the control and $\mathrm{N}$ addition plots for a given depth (Fig. 3). The $\mathrm{H}_{2} \mathrm{O}$-Po concentration was also significantly higher at the $0-10-\mathrm{cm}$ depth than at the 10-20$\mathrm{cm}$ soil depth, but the other three Po fractions were similar

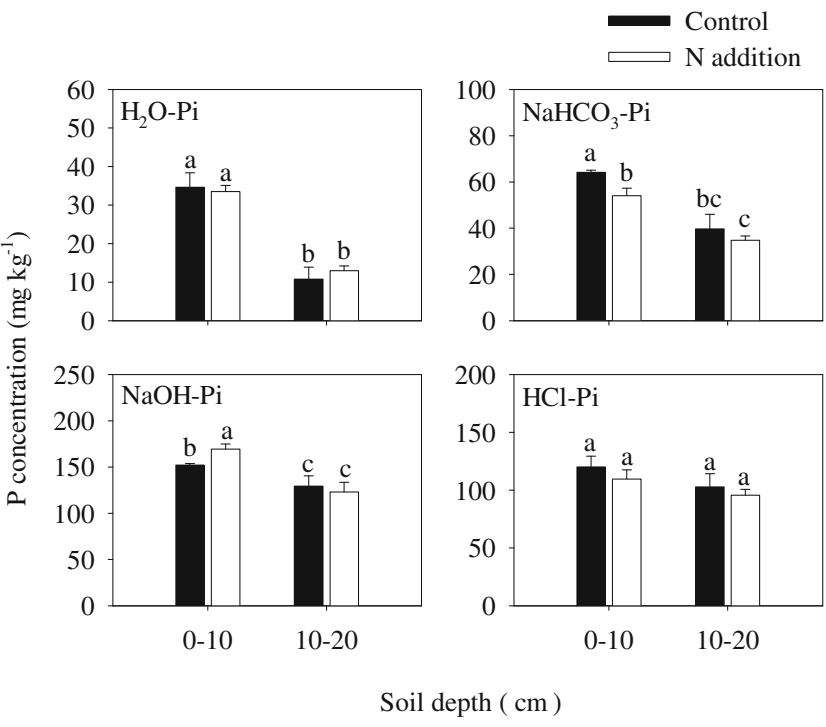

Fig. 2 Changes in soil inorganic phosphorus (Pi) fractions (extracted by $\mathrm{H}_{2} \mathrm{O}, \mathrm{NaHCO}_{3}, \mathrm{NaOH}$, and $\mathrm{HCl}$ ) after 9 years of $\mathrm{N}$ addition in the larch plantation. Bars represent means with standard errors for $n=3$. Different letters indicate significant differences at $P<0.05$ 

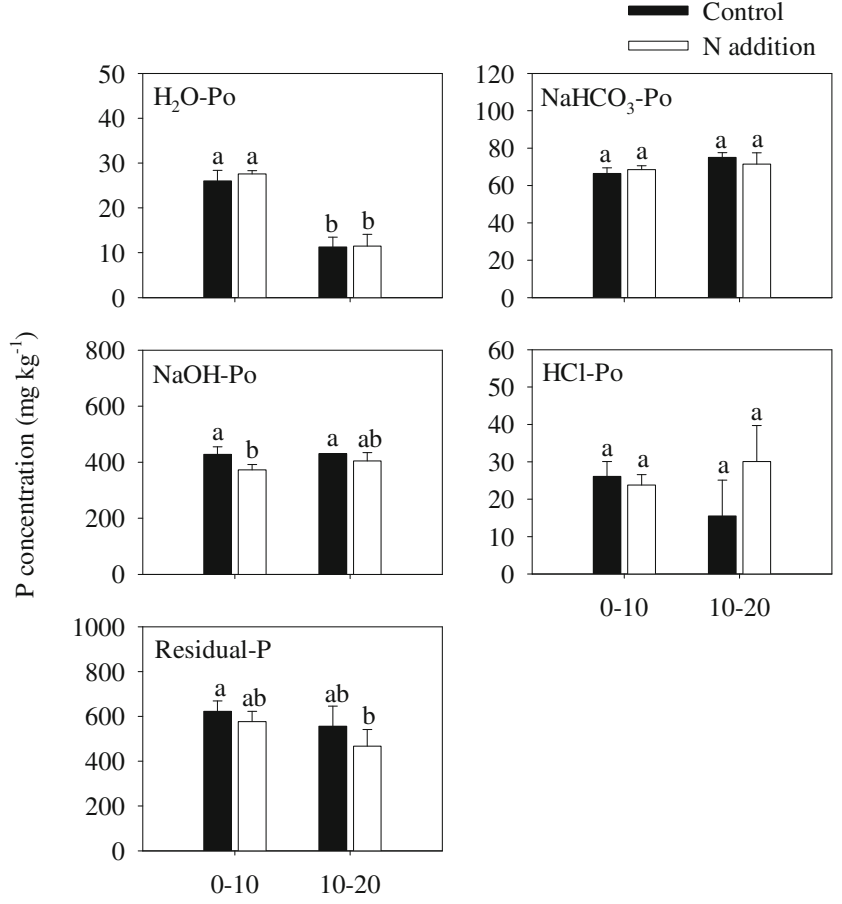

Soil depth ( $\mathrm{cm})$

Fig. 3 Changes in soil organic phosphorus (Po) fractions (extracted by $\mathrm{H}_{2} \mathrm{O}, \mathrm{NaHCO}_{3}, \mathrm{NaOH}$, and $\mathrm{HCl}$ ) and residual $\mathrm{P}$ fraction after 9 years of $\mathrm{N}$ addition in the larch plantation. Bars represent means with standard errors for $n=3$. Different letters indicate significant differences at $P<0.05$

between the two sampling depths. The residue $\mathrm{P}$ concentration did not change with $\mathrm{N}$ addition in both $0-10-\mathrm{cm}$ and $10-20$ cm soil depths.

\subsection{Soil microbial biomass $\mathrm{P}$ and acid phosphatase activity}

Soil microbial biomass $\mathrm{P}$ decreased approximately $40 \%$ after 9 years of $\mathrm{N}$ addition at the $0-10-\mathrm{cm}$ soil depth (Fig. 4). There was no difference in microbial biomass $\mathrm{P}$ concentration between the control and $\mathrm{N}$ addition plots at the $10-20-\mathrm{cm}$ soil depth. The microbial biomass $P$ concentration at the $0-10-\mathrm{cm}$ depth was greater than that at the 10-20-cm depth in same treatment.

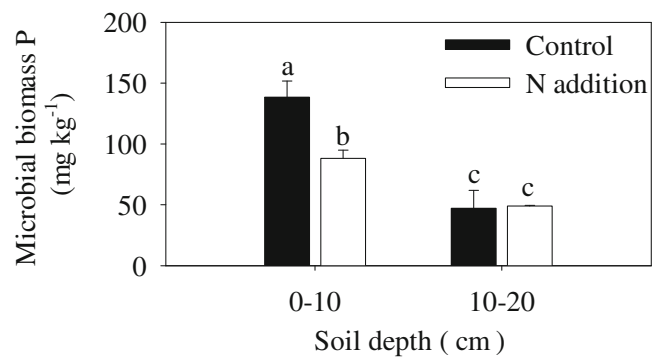

Fig. 4 Changes in soil microbial biomass $\mathrm{P}$ after 9 years of $\mathrm{N}$ addition in the larch plantation. Bars represent means with standard errors for $n=3$. Different letters indicate significant differences at $P<0.05$
$\mathrm{N}$ addition also significantly reduced acid phosphatase activity at the $0-10-\mathrm{cm}$ depth. However, soil acid phosphatase activity in the $\mathrm{N}$ addition plots was not different from that in the control plots at the 10-20-cm depth (Fig. 5). The acid phosphatase activity was approximately 1.5 -fold greater at the $0-10-\mathrm{cm}$ depth than that at the $10-20-\mathrm{cm}$ depth in both the control and $\mathrm{N}$ addition plots.

\section{Discussion}

Our results show that the soil P fraction, microbial biomass $\mathrm{P}$, and acid phosphatase activity are highly responsive to changes in $\mathrm{N}$ applied to the larch plantation. This study has yielded two main findings. First, added $\mathrm{N}$ decreased the concentration of labile inorganic $\mathrm{P}$ in the soil, especially the $\mathrm{NaHCO}_{3}$-Pi concentration. Second, soil acid phosphatase activity decreased after $\mathrm{N}$ addition, and this result contradicts most of our current understanding of the interaction between nutrient availability and microbial function. Based on allocation theory and prior studies conducted in forest ecosystems (Treseder and Vitousek 2001; Saiya-Cork et al. 2002; Marklein and Houlton 2012), N addition should increase acid phosphatase activity. However, we found that $\mathrm{N}$ addition resulted in decreased acid phosphatase activity in the larch plantation.

\section{1 $\mathrm{N}$ addition changes soil $\mathrm{P}$ fractions}

After 9 years of $\mathrm{N}$ addition, soil total $\mathrm{P}$ did not change significantly in the $\mathrm{N}$ addition plots. Total $\mathrm{P}$ content represents the net result between the input of litter and the output of plant uptake. In our study, no significant change was observed in soil total $\mathrm{P}$ between the control and $\mathrm{N}$ treatment, suggesting that the input and output of $\mathrm{P}$ via aboveground and belowground may be in balance. However, the application of $\mathrm{N}$ fertilizer to the larch plantation resulted in a significant decrease in the $\mathrm{NaHCO}_{3}$-Pi concentration in the topsoil compared with the control. This finding disagreed with the result from northern hardwood forests in the eastern USA, where soil $\mathrm{P}$ availability and biotic $\mathrm{P}$ sufficiency differed by tree

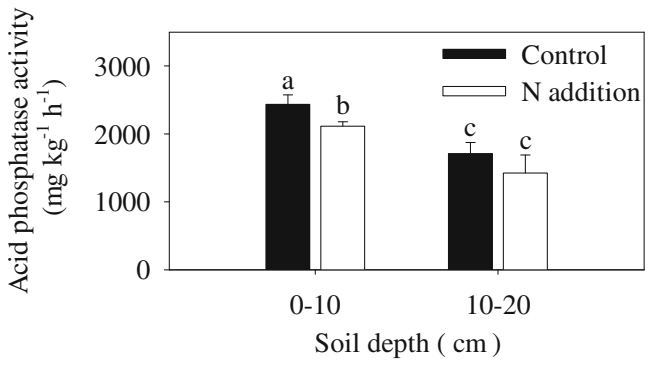

Fig. 5 Changes in soil acid phosphatase activity after 9 years of $\mathrm{N}$ addition in the larch plantation. Bars represent means with standard errors for $n=3$. Different letters indicate significant differences at $P<0.05$ 
species but were unaffected by $\mathrm{N}$ fertilization (Weand et al. 2010b). Weand et al. (2010b) reported that $P$ concentrations in foliar, litter, and fine roots were not affected by $\mathrm{N}$ fertilization. In this study, $\mathrm{N}$ addition stimulates potential net $\mathrm{N}$ mineralization and potential net nitrification processes (Hu et al. 2010) and may increase biotic $\mathrm{P}$ demand. A recent study in our study area showed that $\mathrm{N}$ addition could increase the $\mathrm{N}$ and $\mathrm{P}$ concentrations in the stem, branch, and roots of the larch plantation (Zhao et al. 2010; Table 2). $\mathrm{N}$ addition enhanced $\mathrm{P}$ uptake by trees and might account for the decease of soil $\mathrm{NaHCO}_{3}$-Pi concentration. In this study, the aboveground and belowground biomass, including stem, branch, and coarse root ( $>2 \mathrm{~mm}$ in diameter) biomass, increased approximately $20 \%$ after $\mathrm{N}$ addition in our study area (Gu, Northeast Forestry University, data not published), which may also be attributed to the decrease of soil $\mathrm{NaHCO}_{3}$-Pi concentration. Therefore, $\mathrm{N}$ addition increased plant growth and root $\mathrm{P}$ uptake and then assigned to the different parts of the trees could be responsible for the decrease in the soil $\mathrm{NaHCO}_{3}-\mathrm{Pi}$ concentration (Zhao et al. 2010). However, it should be noted that the decrease in the $\mathrm{NaHCO}_{3}$-Pi concentration observed in this study could also be influenced by soil microbial biomass and activity. A recent study also reported that the contents of microbial biomass and Olsen-P (i.e., $\mathrm{NaHCO}_{3}$-Pi) showed a highly significant linear relationship under different management conditions (Khan and Joergensen 2012). This finding disagreed with the result from an evergreen Mediterranean forest that the decrease in soil available $P$ would reduce the $P$ uptake (Sardans and Peñuelas 2004). Our result was the opposite and such discrepancies may be explained by differences in soil labile inorganic P concentration. In our study, the labile inorganic $\mathrm{P}$ concentration was high, and $\mathrm{N}$ addition might not result in $\mathrm{P}$ limitation or saturation of tree demand for N. Furthermore, mycorrhizae play an important role in the $\mathrm{P}$ uptake by trees. In our study area, we know little regarding mycorrhizal associations important for $\mathrm{P}$ acquisition, or mechanisms of $\mathrm{P}$ uptake. Future investigations comparing mycorrhizal communities between the control and the fertilized plots, and their abilities to access $\mathrm{P}$, could further elucidate the decline of labile inorganic $\mathrm{P}$.

Table 2 Effects of $\mathrm{N}$ addition on nutrient contents in leaf, branch, stem and roots of Larix gmelinii

\begin{tabular}{llllll}
\hline Nutrient contents & Treatment & Leaf & Branch & Stem & Roots \\
\hline $\mathrm{N}\left(\mathrm{g} \mathrm{kg}^{-1}\right)$ & Control & 11.34 & $2.84 \mathrm{~b}$ & $0.92 \mathrm{~b}$ & $7.41 \mathrm{~b}$ \\
& N addition & 11.35 & $3.46 \mathrm{a}$ & $1.37 \mathrm{a}$ & $8.39 \mathrm{a}$ \\
$\mathrm{P}\left(\mathrm{g} \mathrm{kg}^{-1}\right)$ & Control & 2.71 & $0.61 \mathrm{~b}$ & $0.22 \mathrm{~b}$ & $1.56 \mathrm{~b}$ \\
& N addition & 2.54 & $0.83 \mathrm{a}$ & $0.40 \mathrm{a}$ & $2.79 \mathrm{a}$ \\
\hline
\end{tabular}

Plant tissues were sampled in August 2007. Values are means for $n=3$. Different letters for $\mathrm{N}$ or $\mathrm{P}$ within a column indicate significant differences at $P<0.05$. Data in Table 2 are cited from Zhao et al. (2010)
The NaOH-Pi fraction is generally considered the less readily available $\mathrm{P}$ associated with $\mathrm{Fe}$ and $\mathrm{Al}$ oxides and may represent $\mathrm{P}$ adsorption sites (Cross and Schlesinger 1995). In the present study, the $\mathrm{NaOH}-\mathrm{Pi}$ fraction was significantly increased following long-term $\mathrm{N}$ application. $\mathrm{NH}_{4} \mathrm{NO}_{3}$ addition likely enhances soil nitrification, a microbially mediated process of ammonia oxidation with $\mathrm{H}^{+}$as the by-product resulting in soil acidification. The low $\mathrm{pH}$ values in the $\mathrm{N}$ addition plots might enhance the solubility of $\mathrm{Al}^{3+}$ and $\mathrm{Fe}^{3+}$ and then increase the $\mathrm{P}$ binding by $\mathrm{Al}$ and $\mathrm{Fe}$ in the soils (Chen 2003; Dossa et al. 2010). Therefore, the overall combination of changes in the inorganic $\mathrm{P}$ fractions observed in our study demonstrates that $\mathrm{N}$ input may induce a decrease in soil $\mathrm{P}$ availability through changes in plant $\mathrm{P}$ uptake, microbial biomass, and inorganic $\mathrm{P}$ solubilization.

$\mathrm{N}$ fertilization did not increase soil organic $\mathrm{P}$ fractions, although biomass inputs, including stem, branch, and coarse root biomass, increased in the fertilized plots (Gu, Northeast Forestry University, data not published). In the present study, the $\mathrm{NaOH}-\mathrm{Po}$ content was the dominant organic $\mathrm{P}$ fraction. The high content of NaOH-Po in the larch plantation was consistent with previous research in Pinus radiata forest soil (Liu et al. 2004). Interestingly, the larch plantation in this study depleted the $\mathrm{NaOH}-\mathrm{Po}$ fraction, but other organic $\mathrm{P}$ fractions were unaffected by $\mathrm{N}$ addition, suggesting that the $\mathrm{NaOH}-\mathrm{Po}$ pool is important in providing plant-available $\mathrm{P}$ through mineralization. Therefore, the increased growth of L. gmelinii after $\mathrm{N}$ addition, and hence higher nutrient demand, is reflected in the $\mathrm{NaOH}-\mathrm{Po}$ fraction in the soil. It has been suggested that the $\mathrm{NaOH}-\mathrm{Po}$ pool can be the major sink of available $\mathrm{P}$ in the soil and may maintain the levels of plantavailable P through P mineralization (Beck and Sanchez 1994).

\section{2 $\mathrm{N}$ addition effects on microbial biomass $\mathrm{P}$ and acid phosphatase activity}

Soil microbial biomass is an important component influencing plant nutrient availability. In this study, $\mathrm{N}$ addition caused microbial biomass to decrease in fertilized larch plots, supporting the previous finding of $\mathrm{Hu}$ et al. (2010) that soil microbial biomass was lower in fertilized plots in the same study site. There are two potential mechanisms to explain the decrease in soil microbial biomass with $\mathrm{N}$ addition. On the one hand, $\mathrm{N}$ addition could retard mineralization of old and humified soil organic matter (Neff et al. 2002; Hagedorn et al. 2003) then reduce soil labile organic $C$, which is the energy source for soil microorganisms (Sjöberg et al. 2003). On the other hand, soil $\mathrm{pH}$ is an important factor regulating microbial properties. Generally, soil acidification after $\mathrm{N}$ addition could reduce soil microbial biomass and activity (Liu et al. 2011). A recent meta-analysis using 82 field studies after $\mathrm{N}$ addition concluded that microbial biomass declined $15 \%$ on average 
under $\mathrm{N}$ fertilization, and these declines in microbial biomass were more evident in studies of longer duration and with higher total amounts of $\mathrm{N}$ addition (Treseder 2008). Our study site receives a high $\mathrm{N}$ dose compared with other $\mathrm{N}$ addition studies in forest ecosystems (Will et al. 2006; Kritzler and Johnson 2010). Therefore, it is not surprising that microbial biomass was reduced by approximately $40 \%$ after 9 years of $\mathrm{N}$ addition in our study site.

Phosphatase plays a critical role in catalyzing the hydrolysis of organic $\mathrm{P}$ compounds in soil. In general, $\mathrm{N}$ addition is thought to influence $\mathrm{P}$ availability through the N-rich phosphatase enzymes produced by plant roots and microbes. Biota can invest $\mathrm{N}$ into the production of hydrolytic enzymes such as phosphatase for acquiring $\mathrm{P}$ when $\mathrm{N}$ availability is sufficient (Houlton et al. 2008). In addition, the decrease in soil $P$ availability after $\mathrm{N}$ addition would induce higher phosphatase activity. However, we observed that $\mathrm{N}$ addition depressed acid phosphatase activity. This finding disagreed with the results that increasing $\mathrm{N}$ availability or increasing $\mathrm{N}$ deposition increased phosphatase activity (Clarholm and RosengrenBrinck 1995; Turner et al. 2002). Enzyme activity is known to decline with increasing acidity (Weand et al. 2010a), and N application may have acidified the fertilized plots to the point where enzyme activity is suppressed. Therefore, the decrease in acid phosphatase activity observed in the $\mathrm{N}$ addition plots than those in control plots was mainly indirect effect caused by the added $\mathrm{N}$, such as the decrease in $\mathrm{pH}$, rather than a direct result of the increase in soil $\mathrm{N}$ availability.

\subsection{Implications}

This study extends our knowledge of soil $\mathrm{P}$ status in the larch plantation with long-term $\mathrm{N}$ addition. Unlike other studies (Finzi 2009; Weand et al. 2010b), we found that $\mathrm{N}$ addition altered $\mathrm{P}$ distribution and availability in the larch plantation. The soil labile $\mathrm{P}$ pool significantly decreased following long-term $\mathrm{N}$ application. High $\mathrm{N}$ input in some forest ecosystems can increase the growth and nutrient uptake of tree species, thereby leading to a decline in soil $\mathrm{P}$ availability (Will et al. 2006). Soil $\mathrm{pH}$ appears to be another important factor affecting the sorption of Al- and Fe-associated $\mathrm{P}$ and accordingly $\mathrm{P}$ availability in terrestrial ecosystems (Waldrip et al. 2011). In the larch plantation, $\mathrm{N}$ addition inhibited soil acid phosphatase activity and microbial biomass $\mathrm{P}$. The results suggest that $\mathrm{N}$ addition reduced soil $\mathrm{P}$ availability as well as microbial process related to soil $\mathrm{P}$ cycling in the $L$. gmelinii plantation. Although soil types and seasonal effects of $\mathrm{N}$ addition were not investigated, our study confirms soil $\mathrm{P}$ status about responses of larch plantation to $\mathrm{N}$ addition and provides new insights into the causes of these responses. Further research that examines the impact of $\mathrm{N}$ addition on $\mathrm{P}$ status in larch plantation ecosystem with different soil characteristics and sampling time would help assess the generality of our results.

Funding This study was financially supported by the National Basic Research Program of China (2012CB416906), and the National Natural Science Foundation of China (31100466).

\section{References}

Baribault TW, Kobe RK, Finley AO (2012) Tropical tree growth is correlated with soil phosphorus, potassium, and calcium, though not for legumes. Ecol Monogr 82:189-203

Beck MA, Sanchez PA (1994) Soil phosphorus fraction dynamics during 18 years of cultivation on a Typic Paleudult. Soil Sci Soc Am J 58: 1424-1431

Braun S, Thomas VFD, Quiring R, Flückiger W (2010) Does nitrogen deposition increase forest production? The role of phosphorus. Environ Pollut 158:2043-2052

Brookes PC, Powlson DS, Jenkinson DS (1982) Measurement of microbial biomass phosphorus in soil. Soil Biol Biochem 14:319-329

Carreira JA, Garcia-Ruiz R, Lietor J, Harrison AF (2000) Changes in soil phosphatase activity and $\mathrm{P}$ transformation rates induced by application of $\mathrm{N}$ - and S-containing acid mist to a forest canopy. Soil Biol Biochem 32:1857-1865

Chen HJ (2003) Phosphatase activity and P fractions in soils of an 18year-old Chinese fir (Cunninghamia lanceolata) Plantation. For Ecol Manag 178:301-310

Chen XW, Chen LX, Liu WQ (1999) Nitrogen mineralization in different forest soil. J Northeast For Univ 27:5-9 (in Chinese)

Clarholm M (1993) Microbial biomass P, labile P, and acid phosphatase activity in the humus layer of a spruce forest, after repeated additions of fertilizers. Biol Fertil Soils 16:287-292

Clarholm M, Rosengren-Brinck U (1995) Phosphorus and nitrogen fertilization of a Norway spruce forest - effects on needle concentrations and acid phosphatase activity in the humus layer. Plant Soil 175:239-249

Clark RB, Zeto SK (2000) Mineral acquisition by arbuscular mycorrhizal plants. J Plant Nutr 23:867-902

Criquet S, Ferre E, Farnet AM, Le petit J (2004) Annual dynamics of phosphatase activities in an evergreen oak litter: influence of biotic and abiotic factors. Soil Biol Biochem 36:1111-1118

Cross AF, Schlesinger WH (1995) A literature review and evaluation of the Hedley fractionation: applications to the biogeochemical cycle of soil phosphorus in natural ecosystems. Geoderma 64:197-214

Cusack DF, Silver WL, Torn MS, Burton SD, Firestone MK (2010) Changes in microbial community characteristics and soil organic matter with nitrogen additions in two tropical forests. Ecology 92:621-632

Dossa EL, Diedhiou S, Compton JE, Assigbetse KB, Dick RP (2010) Spatial patterns of $\mathrm{P}$ fractions and chemical properties in soils of two native shrub communities in Senegal. Plant Soil 327:185-198

Finzi AC (2009) Decades of atmospheric deposition have not resulted in widespread phosphorus limitation or saturation of tree demand for nitrogen in southern New England. Biogeochemistry 92:217-229

Gong ZT, Chen ZC, Luo GB, Zhang GL, Zhao WJ (1999) Soil reference with Chinese soil taxonomic. Soils 31:57-63 (in Chinese)

Hagedorn F, Spinnler D, Siegwolf R (2003) Increased N deposition retards mineralization of old soil organic matter. Soil Biol Biochem 35:1683-1692

Hedley MJ, Stewart JWB, Chauhan BS (1982) Changes in inorganic and organic soil phosphorus fractions induced by cultivation practices and by laboratory incubations. Soil Sci Soc Am J 46:970-976 
Herbert DA, Fownes JH (1995) Phosphorus limitation of forest leaf area and net primary production on a highly weathered soil. Biogeochemistry 29:223-235

Houlton BZ, Wang YP, Vitousek PM, Field CB (2008) A unifying framework for dinitrogen fixation in the terrestrial biosphere. Nature 454:327-334

Hu YL, Zeng DH, Liu YX, Zhang YL, Chen ZH, Wang ZQ (2010) Responses of soil chemical and biological properties to nitrogen addition in a Dahurian larch plantation in Northeast China. Plant Soil 333:81-92

Jia SX, Wang ZQ, Li XP, Sun Y, Zhang XP, Liang AZ (2010) N fertilization affects on soil respiration, microbial biomass and root respiration in Larix gmelinii and Fraxinus mandshurica plantations in China. Plant Soil 333:325-336

Khan FN, Lukac M, Turner G, Godbold DL (2008) Elevated atmospheric $\mathrm{CO}_{2}$ changes phosphorus fractions in soils under a short rotation poplar plantation (EuroFACE). Soil Biol Biochem 40:1716-1723

Khan KS, Joergensen RG (2012) Relationships between P fractions and the microbial biomass in soils under different land use management. Geoderma 173-174:274-281

Kim YS, Imori M, Watanabe M (2012) Simulated nitrogen inputs influence methane and nitrous oxide fluxes from a young larch plantation in northern Japan. Atmos Environ 46:36-44

Kritzler UH, Johnson D (2010) Mineralisation of carbon and plant uptake of phosphorus from microbially-derived organic matter in response to 19 years simulated nitrogen deposition. Plant Soil 326:311-319

LeBauer DS, Treseder KK (2008) Nitrogen limitation of net primary productivity in terrestrial ecosystems is globally distributed. Ecology 89:371-379

Liu Q, Loganathan P, Hedley MJ, Skinner MF (2004) The mobilization and fate of soil and rock phosphate in the rhizosphere of ectomycorrhizal Pinus radiata seedlings in an allophonic soil. Plant Soil 264:219-229

Liu YY, Dell E, Yao HY, Rufty T, Shi W (2011) Microbial and soil properties in bentgrass putting greens: Impacts of nitrogen fertilization rates. Geoderma 162:215-221

Lü CQ, Tian HQ (2007) Spatial and temporal patterns of nitrogen deposition in China: Synthesis of observational data. J Geophys Res 112:D22S05

Marklein AR, Houlton BZ (2012) Nitrogen inputs accelerate phosphorus cycling rates across a wide variety of terrestrial ecosystems. New Phytol 193:696-704

Mei L, Gu JC, Zhang ZW, Wang ZQ (2010) Responses of fine root mass, length, production and turnover to soil nitrogen fertilization in Larix gmelinii and Fraxinus mandshurica forests in Northeastern China. J For Res 15:194-201

Nave LE, Vance ED, Swanston CW, Curtis PS (2009) Impacts of elevated $\mathrm{N}$ inputs on north temperate forest soil $\mathrm{C}$ storage, $\mathrm{C} / \mathrm{N}$, and net $\mathrm{N}$ mineralization. Geoderma 153:231-240

Neff JC, Townsend AR, Gleixner G, Lehman SJ, Turnbull J, Bowman WD (2002) Variable effects of nitrogen additions on the stability and turnover of soil carbon. Nature 419:915-917

Ohsawa M, Shimokawa T (2011) Extending the rotation period in larch plantations increases canopy heterogeneity and promotes species richness and abundance of native beetles: implications for the conservation of biodiversity. Biol Conserv 144:3106-3116

Olander L, Vitousek P (2000) Regulation of soil phosphatase and chitinase activity by $\mathrm{N}$ and $\mathrm{P}$ availability. Biogeochemistry 49:175-191

Pan YP, Wang YS, Tang GQ, Wu D (2012) Wet and dry deposition of atmospheric nitrogen at ten sites in Northern China. Atmos Chem Phys 12:6515-6535

Paoli GD, Curran LM (2007) Soil nutrients limit fine litter production and tree growth in mature lowland forest of southwestern Borneo. Ecosystems 10:503-518
Saiya-Cork KR, Sinsabaugh RL, Zak DR (2002) The effects of long term nitrogen deposition on extracellular enzyme activity in an Acer saccharum forest soil. Soil Biol Biochem 34:1309-1315

Sardans J, Peñuelas J (2004) Increasing drought decreases phosphorus availability in an evergreen Mediterranean forest. Plant Soil 267: 367-377

Schachtman DP, Reid RJ, Ayling SM (1998) Phosphorus uptake by plants: from soil to cell. Plant Physiol 116:447-453

Sjöberg G, Bergkvist B, Berggren D, Nilsson SI (2003) Long-term N addition effects on the $\mathrm{C}$ mineralization and $\mathrm{DOC}$ production in mor humus under spruce. Soil Biol Biochem 35:1305-1315

Sinsabaugh R, Gallo ME, Lauber C, Waldrop MP, Zak DR (2005) Extracellular enzyme activities and soil organic matter dynamics for northern hardwood forests receiving simulated nitrogen deposition. Biogeochemistry 75:201-215

Tabatabai MA (1994) Soil enzymes. In: Weaver RW, Angle JS, Bottomley PS (eds.), Methods of Soil Analysis. Part 2. Microbiological and Biochemical Properties. SSSA Book Series No. 5. Soil Sci Soc Am, Madison, pp. 775-833

Thomas RQ, Canham CD, Weathers KC, Goodale CL (2010) Increased tree carbon storage in response to nitrogen deposition in the US. Nat Geosci 3:13-17

Tiessen H, Moir JO (1993) Characterization of available P by sequential extraction. In: Carter MR (ed.), Soil sampling and methods of analysis. Canadian Soc Soil Sci, Lewis Publishers, Canada, pp. 75-86

Treseder KK (2008) Nitrogen additions and microbial biomass: a metaanalysis of ecosystem studies. Ecol Lett 11:1111-1120

Treseder KK, Vitousek PM (2001) Effects of soil nutrient availability on investment in acquisition of N, P in Hawaiian rain forests. Ecology 82:946-954

Tu C, Booker FL, Watson DM, Chen X, Rufty TW, Shi W, Hu SJ (2006) Mycorrhizal mediation of plant $\mathrm{N}$ acquisition and residue decomposition: impact of mineral N inputs. Glob Chang Biol 12:793-803

Turner BL, Baxter R, Whitton B (2002) Seasonal phosphatase activity in three characteristic soils of the English uplands polluted by longterm atmospheric nitrogen deposition. Environ Pollut 120:313-317

Vitousek PM, Howarth RW (1991) Nitrogen limitation on land and in the sea: how can it occur? Biogeochemistry 13:87-115

Vitousek PM, Porder S, Houlton BZ, Chadwick OA (2010) Terrestrial phosphorus limitation: mechanisms, implications, and nitrogenphosphorus interactions. Ecol Appl 20:5-15

Waldrip HM, He ZQ, Erich MS (2011) Effects of poultry manure amendment on phosphorus uptake by ryegrass, soil phosphorus fractions and phosphatase activity. Biol Fertil Soils 47:407-418

Wang QK, Wang SL, Liu YX (2008) Responses to N and P fertilization in a young Eucalyptus dunnii plantation: microbial properties, enzyme activities and dissolved organic matter. Appl Soil Ecol 40:484-490

Wang ZQ, Guo DL, Wang XR, Gu JC, Mei L (2006) Fine root architecture, morphology, and biomass of different branch orders of two Chinese temperate tree species. Plant Soil 288:155-171

Weand MP, Arthur MA, Lovett GM, McCulley RL, Weathers KC (2010a) Effects of tree species and $\mathrm{N}$ additions on forest floor microbial communities and extracellular enzyme activities. Soil Biol Biochem 42:2161-2173

Weand MP, Arthur MA, Lovett GM, Sikara F, Weathers KC (2010b) The phosphorus status of northern hardwoods differs by species but is unaffected by nitrogen fertilization. Biogeochemistry 97:159-181

Will RE, Markewitz D, Hendrick RL, Meason DF, Crocker TR, Borders BE (2006) Nitrogen and phosphorus dynamics for 13-year-old loblolly pine stands receiving complete competition control and annual N fertilizer. For Ecol Manag 227:155-168

Zhao Q, Liu XY, Hu YL, Zeng DH (2010) Effects of nitrogen addition on nutrient allocation and nutrient resorption efficiency in Larix gmelinii. Sci Silvae Sin 46:14-19 (in Chinese)

Zhou XH (1994) Long-term research on China's forest ecosystems. Northeast Forestry University Press, Harbin, pp 213-221, in Chinese 